vogius, but died in 1604 as a result of the cruel treatment he had received. Seton is said to have been the real author of the "Novum Lumen Chymicum", a work which was regarded as of the highest importance and was even treated with respect by Newton. John Napier, of Merchiston, the inventor of logarithms, was keenly interested in alchemy, as were his father and his son. William Davidson or Davisson, of Aberdeen (1593-1669 ?), was a chemist rather than an alchemist. He became physician to the King of France and wrote an early text.book of chemistry, "Philosophia Pyrotechnia seu Cursus Chymiatricus" (1633-5), which contains one of the earliest contributions to crystallography.

Acquisitions at the British Museum (Natural History)

Presents to the Department of Zoology include the magnificent mounted head (the largest on record) of an Asiatic wapiti presented by Lieut.-Colonel Price Wood, and a very large mounted specimen of a Tasmanian platypus presented by Sir Frank Crisp. Among the specimens presented to the Department of Mineralogy is a fine set of minerals from Western Australia sent by Dr. E. S. Simpson. This includes remarkably large masses of petalite and its alteration products from a feldspar quarry at Londonderry, near Coolgardie. The petalite, a lithium-aluminiumsilicate, occurs in masses weighing up to a hundredweight. This is the more remarkable as petalite is one of the rarer minerals and until quite recently was only known as comparatively small crystals. In 1935 and 1936, however, a quarry in pegmatite at Varaträsk, Boliden, northern Sweden, yielded many tons of the mineral, and individual crystals were found measuring more than a foot in length. A specimen of this petalite also was presented to the Museum by Prof. P. Quensel. Three fragments of meteoric iron presented by Mr. I. Reinvald, Inspector of Mines, Estonia, are of particular interest as they are part of a lot of about thirty pieces found after laborious search in the neighbourhood of the Lake of Kaalijärv in the island of Oesel. This lake was described in 1827 and many suggestions were made as to its origin. In 1929, Mr. Reinvald made a detailed survey and was convinced that the lake filled a meteorite crater. Five other smaller craters were found in the neighbourhood, but it was only in July 1937 that any metooric iron was found to confirm the theory of their meteoritic origin. Other specimens received include rocks collected by $\mathrm{Dr}$. J. V. Harrison, and Mr. M. H. Donald on excursions in the Urals and the Caucasus, following the International Geological Congress held in Moscow last year, and special mention should be made of a specimen of carved pyrophyllite from China, presented by Mr. B. Cattell, one of the warders in the Museum.

\section{The Universities Bureau of the British Empire}

From the Universities Bureau of the British Empire we have received the report of its executive council for 1936-37. Its membership, as at July 31, 1937, comprised the 19 universities of Great Britain and Ireland, 10 of the 21 Canadian universities, 3 of the 5 South African, 6 of the 17 Indian, the Universities of New Zealand, Malta, Hong-Kong and Rangoon, 6 university colleges and 4 other colleges. A resolution was passed by the Indian Inter-university Board last February to the effect that it was desirable that universities in India should join the Bureau. In addition to indicating briefly the various activities of the Bureau during the year, the report enumerates the subjects that were discussed by the Committee of Vice-Chancellors and Principals of the home universities, by the Australian Vice-Chancellor's Committee and by the Inter-university Board, India. The Bureau's Handbook for Students from Overseas published last year had a very wide circulation, and a new edition was prepared in collaboration with the British Council on British Teachers Abroad, which had prepared a somewhat similar manual relating to institutions other than universities. In the new edition, issued as a joint publication by the two bodies, the information has been amalgamated to form an outline of the facilities for higher education provided by universities and other institutions in Great Britain and Ireland.

\section{Centenary of Le Officine Galileo, Florence}

IN celebration and commemoration of their centenary, the house of $\mathrm{L}_{\Theta}$ Officine Galileo of Florence have issued a striking record of their past and present achievements in the sphere of the manufacture of scientific instruments and other high precision products. They pay tribute also to the men of distinction who have been associated with them and among whom they specially mention the late Marchese Marconi. It has been the privilege of this firm to introduce many instruments of epoch-making importance, and, before 1840, they constructed the circular dividing machine designed by and made to the instructions of Giovan Battista Amici. In 1878, they introduced the Caselli motor for torpedoes. In connexion with astronomical instruments theirs is a long and honourable record; in 1884 they constructed the astronomical clock in the Osservatiorio Ximeniano in Florence, and have but recently completed the 1.20 metre telescope for the University of Padua - a model of which was shown at the Paris Exhibition. Among the early examples of their work illustrated in the commemorative volume are an electric automobile of 1900 , a military gonio. meter, an electric field telegraph and the periscope for the Swedish submarine Hajen of 1902. An interesting contrast between the old and the new can be observed by comparing the illustrations of the theodolites-the spidery construction of the older type is in complete contradistinction to the compact rigidity of the model of to-day, which illustrates how design of fine measuring instruments has been influenced by the high degree of precision attainable in up-to-date manufacturing processes. Among the types of instruments now being manufactured are to be noted such diverse examples as microtomes, dermato-capillariscopes, stereo-cartographs, polarimeters, binoculars and projectors, while a separate list of electrical apparatus shows oscillographs, radio transmitters, measuring instruments, electric pumps and anti-aircraft equipments. 